\title{
Van der Horst, P W 1994 - Hellenism-Judaism-Christianity: Essays on their interaction
}

Kampen: Kok Pharos. 300 Bladsye. Prys: Dfl 69,90

\section{Resensent: Prof Pieter Craffert}

Hierdie agtste volume in die reeks Contributions to Biblical Exegesis and Theology bevat sestien artikels deur Van der Horst waarvan die meeste reeds vroeër gepubliseer is. Die groot verskeidenheid van die artikels en die hoeveelheid temas wat aangesny word, maak dit onmoontlik om enige breè tema of onderwerp te identifiseer vir bespreking. Daarom sal 'n kort oorsig oor die inhoud van die artikels afgesluit word met twee korter opmerkings oor die titel van die boek en oor die waarde van die publikasie vir lesers van hierdie tydskrif. 
Die eerste artikel handel oor die invloed van sekere elemente van Hellenistiese kennis en wetenskap op rabbynse sieninge en die tweede oor die impak van Griekse literêre vorme op Joodse grafinskripsies. Die studie oor die Hellenisering van die Samaritane bevestig hoe veral die Griekse taal die oostelike Mediterreense gebied oorspoel het. Die vierde hoofstuk handel oor twee tekste in Josefus in die lig van Grieks-Romeinse inligting terwyl Van der Horst in die vyfde aantoon hoedat literêre tekste gebruik kan word om ' $n$ inskripsie op ' $n$ nuut ontdekte altaar in Pamfilië te ontrafel. Volgens hom is die inskripsie moontlik deur 'n godvresende geskryf. In 'n uiters relevante artikel wys Van der Horst uit dat daar geen eenduidige siening van die rol en posisie van vroue in antieke Judaïsme bestaan het nie. Dit is belangrik om te besef dat soos in ons eie tyd, daar dikwels in die antieke wêreld 'n skakering van perspektiewe bestaan het.

Hoofstuk sewe gee 'n oorsig oor resente navorsing en insigte oor die ou probleem van die Birkat ha-minim. Dit word gevolg deur twee studies wat onderskeidelik die eksegetiese probleme in Eksodus 22:28 en Esegiël 20:25 aanspreek. Die eerste, wat 'n verbod plaas op die uitskel van 'n ander se gode, en die tweede, wat 'n uitspraak bevat dat sommige van God se wette nie goed is nie, het beide baie interessante rolle in die godsdiensgeskiedenis gespeel. 'n Kort studie oor die invloed van Joodse motiewe in sommige buite-Bybelse bronne rakende die dood van Judas word gevolg deur 'n vertaling en kommentaar op die deel van die Bisantynse teks Suda oor Jesus en die Jode.

Twee studies toon aan hoedat vergelykende materiaal uit Grieks-Romeinse bronne ons in staat stel om Bybelse tekste beter te verstaan. Die een handel oor die verwysing na die altaar vir die onbekende god in Handelinge 17:23 en die tweede oor die enigmatiese teks in Hebreërs 11:11 oor die saadskieting (seminale uitskeiding) van Sara.

In hoofstuk veertien word die tema van die verwoesting van die aarde deur vuur in Hellenistiese, Joodse en Christelike tekste ondersoek. Dit word duidelik dat stilgebed, wat in die antieke wêreld met suspisie bejeën is, in die tyd van die eerste eeu in pagaanse, Joodse en Christelike tekste voorkom en selfs aanvaarbaar geword het. Die laaste studie handel oor geheime hiërogliewe in antieke literatuur.

Beide die titel van die boek en die onderlinge indeling van hoofstukke onder die noemers Hellenisme, Judaïsme en Christendom roep weer die vraag na vore of hierdie terme inderdaad nog geskik is om 'n bydrae te lewer tot die verstaan van die kulturele milieu ten tye van die vroeë Christendom. In die meeste studies is dit duidelik dat die grense wat deur die terme veronderstel word, nie bestaan het nie. Dieselfde temas kom voor in ' $n$ verskeidenheid van tekste - byvoorbeeld die idee van die vernietiging van die aarde deur vuur - en dieselfde kulturele sienings onderlê al die tekste. Is daar nog sin in 'n kunsmatige onderskeid wat klaarblyklik nie meer funksioneel is nie?

Van der Horst se studies wys dat baie min van die temas nie universeel deel van die kulturele milieu was nie. Ooreenstemmende sienings kom in Christelike, Joodse en pagaanse tekste voor. Indien iets soos die geloof in nies as goddelike teken of boodskap 'n byna universele voorkoms het, is dit nie moontlik om na ander kategorieë te kyk om die kulturele patrone te bespreek nie. Moet daar nie eerder van byvoorbeeld wêreldbeeldmetafore gebruik gemaak word om die patrone en breuke in die kulturele samehang van antieke mense uit te druk nie? In kort, dit lyk asof Van der Horst se studies bydra tot so 'n herevaluering maar tegelyk vasgevang sit in 'n baie geforseerde gebruik van uitgediende terme. Die deurmekaarvloei in byna al die artikels van sogenaamde Hellenisme, Judaïsme en Christendom in terme van kulturele milieu, maak die indelings in die inhoudsopgawe oorbodig en die titel van die boek misleidend.

Laastens wil ek enkele opmerkings maak oor die belang van hierdie studies vir die lesers van hierdie tydskrif. Van der Horst bevestig met hierdie studies weer eens die belangrikheid dat Bybelse tekste binne hul kulturele konteks gelees moet word. Hoéwel die bygeloof van nies nie dikwels in die Bybelse tekste vermeld word nie, tel dit onder die talle gelowe in magiese praktyke wat deel van hulle lewensuitkyk 
was - soos sommige Kerkvaders later bevestig. Die studie oor die siening van saadskieting by vroue werp nie net lig op antieke embriologie nie, maar is ook belangrik vir die vertaling van Hebreërs 11:11. Die meeste hedendaagse vertalings het weens etnosentriese sienings van konsepsie, hierdie teks misvertaal. Die ontwikkeling van die siening van stilgebed bevestig dat gebed vir antieke mense binne die raamwerk van magiese praktyke verstaan moet word. So byvoorbeeld is gedink dat 'n gebed wat gehoor is, deur 'n kragtiger gebed ongedaan gemaak kan wörd. In kort, die inagneming van die kulturele milieu van Bybelse tekste is geen opsionele saak nie, maar soos hierdie studies bevestig, essensieel vir enige ernstige interpreteerder van daardie tekste. Hierdie bundel van Van der Horst kan daarom met vrymoedigheid aanbeveel word vir enige leser wat op die hoogte wil kom met die kulturele milieu van die Bybelse tekste. 